Catherine Mary MacRobert University of Oxford

catherine.macrobert@lmh.ox.ac.uk

\title{
Re-evaluating the Psalterium Sinaiticum: the Limitations of Internal Reconstruction as a Text-Critical Method
}

\begin{abstract}
MacRobert Catherine Mary, Re-evaluating the Psalterium Sinaiticum: the Limitations of Internal Reconstruction as a Text-Critical Method. "Poznańskie Studia Slawistyczne" 14. Poznan 2018. Publishing House of the Poznań Society for the Advancement of the Arts and Sciences, pp. 149-167. ISSN 2084-3011.
\end{abstract}

The Psalterium Sinaiticum, a Glagolitic manuscript containing an Old Church Slavonic version of the Book of Psalms, has usually been treated, since its discovery in the later nineteenth century, as representative of the translation made by SS Cyril and Methodius before 869 . Yet its textual status is in two ways problematic: it exhibits a number of idiosyncratic features (verse divisions, headings, variant readings, lexical peculiarities) which set it apart from other Church Slavonic psalter manuscripts, even those which are generally referred to the same early redaction and CyrilloMethodian tradition; it displays marked internal inconsistencies for which there is no simple explanation, such as correlation with the various changes of scribal hand in the manuscript. Von Arnim used the distribution of these inconsistencies as evidence to support an internal reconstruction of several distinct stages in the manuscript tradition underlying the Psalterium Sinaiticum. His argumentation implies that in fact the text of this manuscript stands at some distance from the original translation of SS Cyril and Methodius. On the basis of new comparative evidence from the second Glagolitic psalter manuscript discovered on Sinai in 1975, this paper reviews von Arnim's analysis and its effectiveness as a text-critical method, and draws conclusions about the place of the Psalterium Sinaiticum in the Cyrillo-Methodian tradition.

Keywords: manuscript transmission; textual tradition; Psalterium Sinaiticum; Psalterium Demetrii

The Psalterium Sinaiticum (hereafter Ps. Sin), a Glagolitic manuscript containing an Old Church Slavonic version of the Book of Psalms discovered in the later nineteenth century (Sever'janov, 1922; Altbauer, 1971) and augmented in 1975 (Tarnanides, 1988; Mareš, 1997), has usually been regarded as representative of the translation made by SS Cyril and Methodius before 869 . Yet its textual status is in two ways problematic: 
- it exhibits a number of idiosyncratic features (graphical and lexical peculiarities, variant readings, headings and glosses, verse divisions) which set it apart from other Church Slavonic psalter manuscripts, even those - notably the Tolstoy, Pogodin, Sofia, Bologna and Vienna commentated psalters (Jagić, 1907, Hamm, 1967) and the version found in the Croatian tradition (Valjavec 1889-1890, Vajs 1916) - which are generally referred to the same early redaction and Cyrillo-Methodian tradition;

- it displays marked internal inconsistencies for which there is no simple explanation, such as correlation with the various changes of scribal hand in the manuscript.

In his monographic investigation of the manuscript von Arnim uses the distribution of these inconsistencies as evidence to support an internal reconstruction of several stages in the manuscript tradition underlying Ps. Sin (Arnim, 1930, 17-20, 48-58). In summary (Kul'bakin, 1933, 244; Penkova, Karačorova, 2003, 618), he posits an immediate antigraph (X), copied in turn from an exemplar written by two scribes, one (Y) up to the end of ps. 76, the other $(Z)$ for the rest of the text; prior to this he postulates a Bulgarian stage of transmission (O) and a still earlier Moravian version (P), derived from but not necessarily the same as the original translation. His analysis also implies that the text of this manuscript stands at some distance from the original translation of SS Cyril and Methodius.

Von Arnim's argumentation depends on the availability of recurrent patterns of usage and correct identification of changes in scribal hand. On both these scores his position is open to challenge. No doubt in order to have a solid basis of frequently occurring data for his conclusions, he relies primarily on orthographic and inferred phonological data, supplemented by morphology and to a limited extent by lexical variants. This approach tends to conflate (Vaillant, 1932, 69) two processes which may be closely associated with each other in practice, but are separable in principle: manuscript transmission, as signalled by changes, typically unsystematic or unintentional, in spelling or morphological forms, and the more deliberate or even systematic changes which mark the development of a textual tradition. Moreover, some of the peculiarities which von Arnim attributes to particular reconstructed stages of transmission are so limited in their occurrence that they may simply be scribal errors in the palpably erratic Ps. Sin (Vaillant, 1932, 70; Kul'bakin, 1933, 247). 
Von Arnim himself recognizes that identification of the scribal hands in Ps. Sin is crucially bound up with the reconstruction of its antigraph: „Nehmen wir eine fast ganz homogene Vorlage an, so können die Partie II, IV, VIII und XA unmöglich von einen und demselben Schreiber herrühren" (Arnim, 1930,18). He chooses instead to assume a heterogeneous source and to attribute sections II, IV, VIII und XA, i.e. folios $10-39 \mathrm{v}$, 44-46 and most of $82-129 \mathrm{v}$, to one of the three scribes whose work he detects in the manuscript. However, von Arnim's conclusions about changes in hand seem to have been based more on orthographical than on palaeographical evidence (Altbauer 1971: xii). On the basis of photographs, as well as the divergent orthographical practices in these sections, Kul'bakin challenges von Arnim's analysis, suggesting that section II and sections IV, VIII and XA were written by two different scribes, and also that the scribe who wrote sections V and XII may not have written section III, as von Arnim supposed (Kul'bakin 1933: 242, 248-250). As Kul'bakin points out, if some of the variation in the manuscript can be explained as differences in usage among the scribes themselves, rather than as traces of putative earlier stages in transmission, then the evidence for von Arnim's reconstructions is substantially diminished. Kul'bakin is sceptical in particular about the grounds for positing two intermediate stages, $\mathrm{X}$ and $\mathrm{Y}+\mathrm{Z}$, between Ps. Sin and the source from which it inherited a scattering of highly conservative features. His surmise that at least five scribes were involved in writing Ps. Sin has won support from more recent palaeographical scrutiny by Lunt and Ilčev (Lunt, 1957; Altbauer, 1971, 359-360; Ilčev, $1979,203-205)^{1}$, who concur in identifying four main scribes and six or more possible assistants, thus tending to vindicate Sever'janov's estimate (Sever'janov, 1922, vii and passim). At least two of those four scribes appear also to have been responsible for writing the part of the manuscript discovered in 1975 (Fetková, 2000, 115).

Recently Temčin has revived von Arnim's type of argumentation in application to the distribution of the letters $\$$ (Temčin, 1998) and $Q$ (Temčin, 2004) in Ps. Sin. Starting from the identification of scribal hands

${ }^{1}$ Ilčev tacitly corrects the printing error in Lunt's exposition by which folios 50-81 appear to be attributed both to scribe $A$ and to scribe $\mathrm{G}$. He also adopts a method of labelling the main scribes as A, B, C, D and their assistants as A', B', B", B"', C', C" which more clearly reflects the palaeographical structure of the manuscript than Lunt's sequential labelling $\mathrm{A}-\mathrm{I}$. 
put forward by Lunt and Ilčev, he concludes that, although all the scribes were familiar with the letter $\mathrm{z}$, three of the main scribes and a minor one ${ }^{2}$ tended to follow their exemplar in using woo, while the fourth and some of the minor ones ${ }^{3}$ adhered to an orthographical norm which preferred $\mathrm{s}$. He then extends this interpretation to account for the fact that the same three scribes use the letter 9 freely in initial position, while the fourth and two minor ones ${ }^{4}$ restrict it to the prefix oT-, again, he suggests, in accordance with their own orthographical norm. This analysis has a more secure palaeographical basis than von Arnim's reconstruction of a stage at which the first half of the text (Y) was characterized by $\mathrm{w}$ and the second half (Z) by wण् (Arnim, 1930, 19, 198); but the increasing use of w within a substantial portion of the manuscript written by one scribe tempts Temčin to forgo this security and speculate that a change of hand may have gone undetected (Temčin, 1998, 110). An obvious alternative would be to suppose

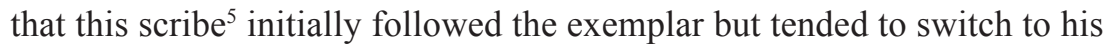
own norm. More importantly, Temčin's arguments depend on his assertion that wor is older than ${ }^{\prime}$; but this is a possibility rather than a generally accepted view (Marti, 2004, 410-412; Velčeva, 1999, 90; 2000, 44). The reverse assumption, that $\mathrm{s}$ belonged to an earlier stage than wo, would entail different conclusions about both the exemplar and the habits of the various scribes, including their use of $Q-$. In any case the letter $Q-$ is employed in Ps. Sin as a presentational marker at the start of verses or versicles, rather than as a feature of orthography proper, and its use could well have been a feature of local practice applied in different ways by the various scribes.

Behind these specific problems lies a more general one. Orthographical data may seem to offer plentiful and therefore solid evidence for manuscript transmission; but in reality their interpretation is complicated by the difficulties of distinguishing between simple slips of the pen and deviations from the inherited norm which betray a change in pronunciation, between involuntary inconsistencies on the part of an incompetent scribe and legitimate variation within flexible orthographical rules, between the scribe who at first follows his exemplar but gradually imposes the rules of spelling

\footnotetext{
${ }^{2}$ Ilčev's B, C, D and C'.

${ }^{3}$ Ilčev's A, B', B" and especially B"'.

${ }^{4}$ Ilčev's A, B"' and C'.

${ }^{5}$ Ilčev's D.
} 
which he has learnt and his colleague who attempts to follow those rules but gradually reverts to copying what is in front of him, between the older usage of an antigraph and the conservative norm of a scriptorium.

The last of these complications is particularly relevant to Ps. Sin. Neither von Arnim nor Temčin engages with the problem highlighted by Kul'bakin, that all the scribes of Ps. Sin adhere to the use of a single front nasal vowel letter $э €$. Von Arnim does note that this feature, like the rare letter tr which can be detected in parts of Ps. Sin written by three different scribes ${ }^{6}$ (Temčin, 2004, 509), must go back at least to the antigraph X; indeed these two peculiarities provide an important part of his justification for positing $\mathrm{X}$ as a separate stage. Yet the practice of using $\boldsymbol{\jmath} \in$ in all positions is otherwise found consistently only in the Kiev and Prague Folia and the Ohrid Bifolium and is thought to be early (Velčeva, 1999, 90). If von Arnim's reconstruction is accepted, then either this practice was still in force at the times and places where both Ps. Sin and X were written, although in other respects their orthography is not particularly conservative; or the scribes of Ps. Sin, $\mathrm{X}, \mathrm{Y}+\mathrm{Z}$ and $\mathrm{O}$ all contrived to retain consistently an inherited usage, even while they introduced a number of divergent orthographical and linguistic features. The first possibility is without parallel in the admittedly modest corpus of early Glagolitic manuscripts; the second is intrinsically implausible. This is why Kul'bakin proposes a less elaborate manuscript transmission, with fewer stages between Ps. Sin and von Arnim's P (Kul'bakin, 1933, 246, 250-251).

The discovery and publication of the second Sinai Glagolitic psalter manuscript (Miklas et al. 2012), the Psalterium Demetrii (hereafter Ps. Dem) sets the peculiarities of Ps. Sin in a new light. These two manuscripts have in common some significant peculiarities: sporadic use of non-Glagolitic, especially Cyrillic, letters; a tendency to confuse $Q$ and $v \breve{u}$ - with $u$ (Arnim, 1930, 76, Kul'bakin, 1924, 181, Miklas et al., 2016, 35-37); some highly conservative linguistic features and occasional shared errors (MacRobert, 2016, 92-96); unusual types of verse division (MacRobert, 1993, 79) and headings to the psalms (MacRobert, 2014, 176); and some shared marginalia (MacRobert, 2014, 180). They belong not only to the same cultural and linguistic background but also to the same textual

${ }^{6}$ Ilčev's A, C and D. 
tradition, yet neither is affiliated to the other: each contains independent errors and reminiscences. On the whole Ps. Dem is rather less conservative than Ps. Sin (MacRobert, 2016, 93, 97), but occasionally it corrects a shared error ${ }^{7}$, has a better reading (MacRobert, 2014, 183), or retains an older variant (MacRobert, 2016, 94). Thus it is an important witness to the early textual tradition of the Church Slavonic Psalter.

To anyone seeking to reconstruct manuscript transmission, however, Ps. Dem offers a salutary warning about the rapidity with which earlier scribal usage can be obscured by copyists. Preliminary studies (Velčeva, 1999, 92-96; Miklas, 2016, 31-32) show that the scribes of this manuscript had different orthographical habits from those of Ps. Sin and, by implication, of its antigraph: denasalization of $q$ to $u$ is frequent throughout; both the main scribe (A) and the one who wrote ff. $2 \mathrm{v}$ and $3 \mathrm{v}-14 \mathrm{r} 11$ (B) prefer to use the back jer only ${ }^{8}$, employ w much more often than wro, and differentiate between $€$ (after consonants) and $э €$ (initially and after vowels). Possible traces of orthographical practice shared with Ps. Sin are detectable mainly on ff. $14 \mathrm{r} 12-34 \mathrm{r}$, the section written by the third scribe (C), who uses both jers, шण् more frequently than $₫$, and sometimes $æ$ after consonants ${ }^{9}$. In the whole text of the psalms there are only three instances of Glagolitic $\Phi^{10}$, and there is no trace of the letter tr. Thus the evidence of Ps. Dem, while it does not actually conflict with Temčin's interpretations, provides little further corroboration for them. More detailed study of orthographical variants in Ps. Dem may permit the partial reconstruction of an immediately prior manuscript stage; but it seems unlikely that this will bear a marked resemblance to Ps. Sin. This is not surprising: the nearest possible relationship between the two extant manuscripts would be a common antigraph, and it seems likely that at least one copy intervened between this and Ps. Dem.

Equally, Ps. Dem does not assist reconstruction of the earlier manuscript stages which von Arnim posits for Ps. Sin. There is no trace of the change at ps. 77 from с'ВАильна to с'ВА,ильно on which his hypothesis of

${ }^{7}$ For instance in ps. 71:10 and 96:1 the corruption of отоци to отьц or even оци is found in both manuscripts, but Ps. Dem corrects to отоц in ps. 96:1.

${ }^{8}$ However, front jer reappears sporadically in pss. 78-106.

${ }^{9}$ Mainly in the pronouns MrA and cta.

${ }^{10}$ As initial letter of the verse in 18:9 (scribe C), 36:23 and 44:2 (scribe A). 
a manuscript with two scribes, Y and Z, is based. In von Arnim's study Bulgarian interventions at an earlier manuscript stage $\mathrm{O}$ are invoked to account for the parallel switches in Ps. Sin from р'вснота and пом'внжти to истина and поманжти (Arnim, 1930, 67-68). In fact, however, the distributional association between истика and помамжти is not quite as strong in Ps. Sin as von Arnim suggests, and it is still weaker in the portion of the manuscript discovered in 1975, which has p'sсnота and its derivatives x7, истина х3, but поманжти х7, пом'Бнжти х1. More importantly, it cannot be detected in Ps. Dem: with one exception (ps. 39:11), истина has supplanted p'вснота throughout, х36, and there is no linkage with поманжти, which осcurs only once (ps. 131:1), where Ps. Sin has пом'вктти. The unusual forms

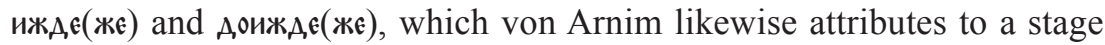
of Bulgarian influence, are as numerous in Ps. Dem as in Ps. Sin but dif-

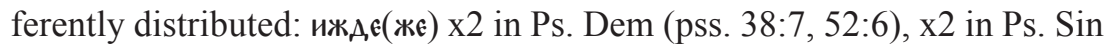
(pss. 48:18, 83:4); АонжАєє(ж) $x 4$ in Ps. Dem (pss. 57:8, 103:33, 140:10, 145:2), x5 in Ps. Sin (pss. 71:7, 93:15, 109:1, 122:2, 131:5) and x3 in both manuscripts (pss. 93:13, 111:8, 141:8). Thus three features which in von Arnim's analysis of Ps. Sin are referred back to the same stage receive different treatments in Ps. Dem. The generalization of истина need not be a specifically Bulgarian innovation; it is consistent with the early and limited attestation of the Moravianism p'sснота in Old Church Slavonic. The provenance and chronology of the other two features are uncertain, but the simplest inference is that both поманжти and the forms in -жа, more frequent or even regular in the shared source of Ps. Sin and Ps. Dem, and that the substitution of пом'ьктти and incipient introduction of forms in $-A \in$ reflect local usage common to the scribes of the two manuscripts. At all events the witness of Ps. Dem does not assist the reconstruction of manuscript transmission further back than the source from which it and Ps. Sin derive.

Ps. Dem does however offer valuable evidence about textual tradition, in particular about the processes of intentional revision by which elements perceived by scribes as alien or incorrect were removed from the text. The combined witness of Ps. Sin and Ps. Dem suggests that the survival rate of such elements was in inverse proportion to their prominence and frequency. This is understandable if one considers what is involved in the process of correcting a text manually: it is difficult to introduce systematic corrections 
for a number of disparate features concurrently, especially if some of those features are occasional or isolated. Inevitably the corrector will tend to focus on corrections which have to be made frequently and are easy to recognize, to the neglect of less common or straightforward ones. So if the distinctive graphic, linguistic and textual features of Ps. Sin and Ps. Dem are categorized according to their putative original frequency and actual attestation, the following staged sequence of revisions, A1-A3, can be inferred.

\section{A1. Removal of frequent or regular West Slavonic $* t j>c$ and $* d j>z$}

This is a systemic, geographically conditioned orthographical change, from one distinct variety of Church Slavonic to another. These phonological reflexes must have been alien to South Slavs, and Ps. Sin is unusual among Old Church Slavonic manuscripts in retaining one clear example of each, освьаце in the heading to ps. 29 and мев'взества in ps. 24:7. Ps. Dem. has lost them, but provides a further example in the gloss to ps. 77:46, pьз' which has been corrupted in Ps. Sin (MacRobert, 2014, 183). It is surely no accident that two of these vestigial forms bear a marginal relationship to the text, occurring in a heading or gloss which may not have been fully intelligible to scribes, while a third is found in a word formation which is already replaced by мєв'ВА'Вни' in Ps. Dem and the subsequent textual tradition ${ }^{11}$. Presumably the numerous instances of these reflexes which would have been more readily identifiable in text had already been extirpated.

\section{A2. Removal of other recurrent alien or antiquated usages}

Even in Ps. Sin. the prefix BZ1- (Lencek, 1993) is found only x10, somewhat inconsistently, in a small set of verbs denoting physical movement (pss. 5:11, 35:13, 36:28, 43:3, 48:8, 49:17, 79:9, 100:5, 108:10,

${ }^{11}$ There is a striking parallel in the formations pозьство and порозьство attested in Codex Marianus and Codex Clozianus alongside рождение and порождениє (Jagić, 1883/1960, 572; Dostál, 1959, 367, 376; Večerka, 2012, 408). 
118:157); ${ }^{12}$ in Ps. Dem there are at most two instances of it (MacRobert, 2016, 93). Similarly, as explained above, the word p'вснота, which occurs more frequently in Ps. Sin than истина, disappears almost entirely from Ps. Dem. As mentioned above, the use of a single front nasal vowel letter $\mathfrak{\jmath}$, which allies Ps. Sin to the West Slavonic Kiev Folia, can be detected only vestigially in Ps. Dem, and the letter st, whose early use in Ps. Sin is supported by various acrostich compositions and listings of the Glagolitic alphabet (Marti, 2004, 407), is already lost from Ps. Dem.

Multiple instantiations of a feature may persist in shared patterns which provide clues to relationship between manuscripts: so вратр- occurs x3 in Ps. Sin (pss. 21.23, 48:8, 151:2), x1 in Ps. Dem (ps. 34:14), x3 in both (pss. 49:20, 68:9, 121:8), indicating the beginnings of divergent transmission from a common starting point, whereas the Pogodin and Sofia manuscripts manifest a slightly closer mutual affinity by retaining this form in the same places $x 4$ (pss. 21.23, 34.15, 49:20, 68:9). More importantly, the variation in the translation of Greek $\delta \omega \rho \varepsilon \alpha ́ v$ between дшоуть (ps. 34:7 and 19) and спвıти (pss. 68:5, 108:3, 118:161, 119:7) which occurs in both Ps. Sin and Ps. Dem is mirrored in the Tolstoy and Pogodin ${ }^{13}$ psalters, the Croatian tradition (Šimić, Makarijoska, 2013, 34) and even the tenth-century translation of the commentary on the psalms by Theodoret of Cyrrhus (Pogorelov, 1910, 123). This suggests that the divergent textual traditions of the psalter used in devotional practice and the two commentated versions all go back to a single early stage of revision.

\section{A3. Gradual eradication of occasional alien or antiquated features}

In a few places Ps. Sin and Ps. Dem attest words or forms which have otherwise disappeared completely from the textual tradition of the Church Slavonic Psalter and are rare in Old Church Slavonic: мичьже ${ }^{14}$ (ps. 38:6), поконz ${ }^{15}$ (ps. 110:10) rather than NАчАло, фараост (ps. 134:9) in contrast

\footnotetext{
${ }^{12}$ Again Codex Clozianus offers one or two parallels, вzıмести and въıиспхъмити (Dostál, 1959, 327).

${ }^{13}$ Indirectly also in the Sofia psalter, which however replaces дшоуть with вєзоумд.

${ }^{14}$ Also attested in Codex Clozianus (Dostál, 1959, 357).

${ }^{15}$ Possibly attested in corrupted form in Codex Clozianus (Dostál, 1959, 366).
} 
to the more usual фapaonz ${ }^{16}$, and the unusual spelling a $(\mathbf{z})$ Taps which occurs twice in Ps. Dem (pss. 25:6, 117:27) and once in both manuscripts (ps. 42:4). Other shared peculiarities, such as Балии (ps. 87:11), мътто (pss. 14:5, 25:10), пр'вА' (ps. 16:13), пр'єкоущена (ps. 44:10 and 14), are still attested in some conservative psalter manuscripts, particularly the Tolstoy, Pogodin and Sofia commentated psalters, and in the Croatian tradition (MacRobert, 2016, 93, 95; Šimić, Makarijoska, 2013, 30-38, 2015: 638-640); the spelling длєлоуи' (MacRobert, 2014, 176) is paralleled in the Tolstoy psalter and sporadically in other Old Church Slavonic and Croatian sources.

The main effect of revisions A1-A3 is systemic change from a West Slavonic to a South Slavonic recension. Presumably other Cyrillo-Methodian translations which survived from the Moravian period underwent similar change, and it is a matter of chance, or luck, that the stages in that change are better attested for the Psalter. In the sequence Ps. Sin occupies a position early in the second stage, while Ps. Dem can be located at the beginning of the third stage. Its witness is not crucial to the hypothesis of staged revision, but at each stage it supplies a small amount of clarifying and corroborating evidence, and so helps to fill the gap between Ps. Sin and vestigially conservative manuscripts such as the Pogodin and Sofia psalters.

However, there is a further set of revisions, B1-B3, which are specific to the Psalter, a text whose poetic structure and liturgical use set it apart from other biblical books, while its ancient Hebrew background makes it sometimes difficult or even obscure in Greek as well as in Church Slavonic. Here the contribution of Ps. Dem is more important, because similarities and coincidences between it and Ps. Sin indicate that processes of explanatory re-wording and revision on the basis of Greek had already started when these manuscripts were written.

\section{B1. Glossing of foreign words}

The number of glosses found in both Ps. Sin and Ps. Dem is small, but crucial for the hypothesis of a common source (MacRobert, 2014, 180-181). It is also significant that two of them explain or translate

${ }^{16}$ Already found in Ps. Dem, ps. 135:15. 


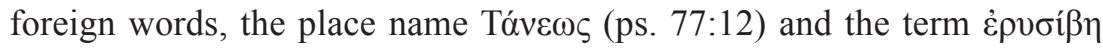
(ps. 77:46), glossed as рьзь in Ps. Dem. A third example can be detected in Ps. Sin, where чрzмгцна (ps. 77:47) appears both as a marginal gloss on

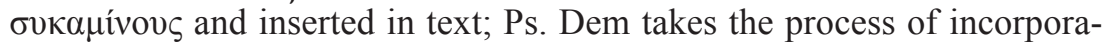
tion further, eliminating the marginal gloss.

It is plausible to suppose that the interpretative rendering of $K \eta \delta \alpha \rho$ as темьна' (ps. 119:5), which is borrowed from the Church Slavonic translation of the pseudo-Athanasian commentary on the psalms, was also first introduced as a gloss and subsequently integrated into text in Ps. Sin and

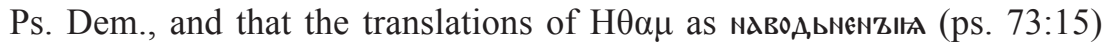

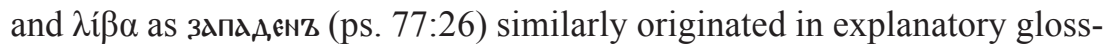
ing (MacRobert, 2010, 426-427); the exegetical note on ps. 88:13 found in both manuscripts provides further evidence of a shared interpretative source (MacRobert, 2014, 180, 182). Similarly, the use of крастьки in

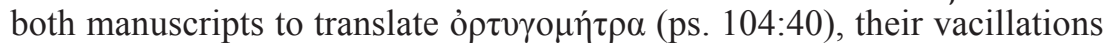
between the loanword сканд, 'А Ps. Dem, 140:9 in both) and its translation as сZБлазмz (pss. 49:20, 139:6 in Ps. Dem, 68:23 in Ps. Sin, 118:165 in both), the choice of мZішицюA in Ps. Sin rather than cкZıмın in Ps. Dem (ps. 104:31), and the shift from олокавZтомата (pss. 19:4, 39:7) tо вьсесъжагаєма' (pss. 49:8, 50:18 and 21, 65:13 and 15) in Ps. Dem, all seem to reflect a desire to maximize intelligibility for a Slav readership. Of the two manuscripts, Ps. Sin takes this tendency further, generalizing вьсесъжагаєма' throughout and adding five more marginal glosses on Greek loanwords (MacRobert, 2014, 180-181). Ps. Dem has only one other gloss, сzставz for vпостась (ps. 88:48), but it offers more instances of substitution in text, replacing варьи with стьнz (ps. 44:9) and both тоумванz and коумвалz with кемzпанz (pss. 149:3, 150:4 and 5).

Just how many of these glosses and interpolations go back to the shared source is impossible to determine with certainty; but the fact that cr'bNz and кємZחаNZ also appear in conservative representatives of the commentated and the devotional traditions, the Vienna and Dečani psalters (Mitrevski, 2000), indicates a wider and perhaps an earlier currency than that enjoyed by the additional glosses in Ps. Sin. The same applies to the glossed expressions inherited by Ps. Sin and Ps. Dem: they are all attested in other parts of the tradition, but to varying degrees: on the whole manuscripts containing 
the translation of the pseudo-Athanasian commentary exhibit more Greek loanwords than the devotional versions. So forms of the Slavonic word for 'rust' become standard in early devotional psalters, both Cyrillic and Croatian Glagolitic, while the Greek loanword is found in the commentated Tolstoy, Pogodin, Sofia, Bologna and Vienna psalters. The majority of these commentated psalters retain the Greek loan сикаминие, though the Pogodin psalter, together with the devotional Dečani psalter, opts for чрzмцца (Ribarova, 2005, 142), as in Ps. Sin and Ps. Dem. The consistent use of сканд'Ал and олокавътомата in the Croatian tradition (Šimić, Makarijoska, 2013, 28-30, 2015: 635-636) could be due in part to the influence of Latin scandalum and holocausta, but the early dissemination of скан, $\mathrm{B} \mathrm{\textrm {B }} \mathrm{\textrm {Z }}$ as a loan from Greek is guaranteed by its attestation in the East Slavonic Tolstoy commentated psalter (pss. 118:165, 139:6, 140:9), ${ }^{17}$ and олокавZтомата generally predominates over вьсесъжагдємдь in manuscripts containing the pseudo-Athanasian commentary (MacRobert, 2010, 425-426). The loanword скZıмıп is found independently of Latin in the Croatian tradition (Šimić, Makarijoska, 2015, 636) and in the Tolstoy and Dečani psalters (Ribarova, 2005, 143), which also opt, together with the Vienna psalter, for ортигомитра (Ribarova, 2005, 50), though the Pogodin, Sofia and Bologna psalters prefer the translations мZшшицА and краст'вли. The interpretative replacement of foreign words is also characteristic mainly of the devotional textual traditions: two instanc-

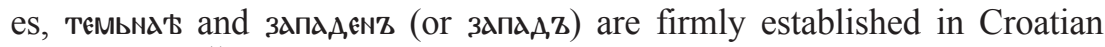
manuscripts (Šimić, Makarijoska, 2013, 30) and occur sporadically in early devotional psalters written in Cyrillic (MacRobert, 2010, 426); the third, NABOA, ВNENZIFA, is apparently alien to the Croatian tradition, but has made its way into the commentated Bologna psalter. The direction and motivation of change is sometimes difficult to determine, and the presence of loanwords may of course be due partly to secondary influences, from Greek when the pseudo-Athanasian commentary was added or from Latin in the Croatian area. On balance, however, it seems likely that the earliest recoverable stage in the textual history of the Church Slavonic Psalter, as of other translations, was characterized by a relatively high incidence of loanwords and that the substitution of Slavonic equivalents had already begun in the source from which Ps. Sin and Ps. Dem derive.

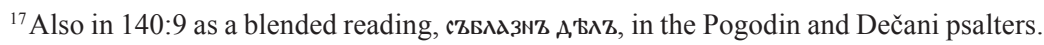




\section{B2. Translational corrections}

In addition to glosses on loanwords, Ps. Sin contains some marginal annotations proposing alternative translations, which seem to reflect the linguistic usage associated with the Church Slavonic translation of Theodoret's commentary on the psalms (Thomson, 1998, 801; MacRobert, 2014, 179-181). Ps. Dem has a couple of similar though less distinctive marginal corrections, and the two manuscripts share one gloss of this type,

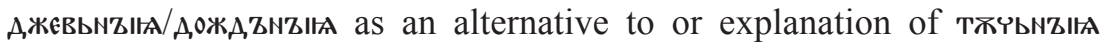
(ps. 77:44). Generally speaking, however, the distinctive translational choices which are to be found in both Ps. Sin and Ps. Dim, such as оржжzіxz

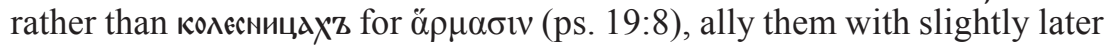
witnesses to the textual development of the devotional psalter (MacRobert, 2016, 96-102).

However, each of the two manuscripts is differentiated from the other by a small number of highly unusual variant readings, some of which seem to be inspired by a more literalistic approach to translation than is seen elsewhere in the early tradition of the Church Slavonic Psalter, and which are mostly concentrated towards the end of the text. For this reason, no doubt, their presence in Ps. Sin has not attracted much attention,

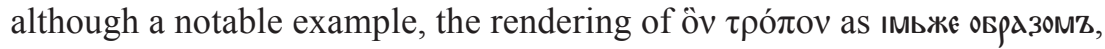
rather than 'ккоже (ps. 41:2) as in Ps. Dem and other early manuscripts, has been known for a long time. To these may now be added from the part of Ps. Sin discovered in 1975 such literal translations as вzноушнатz

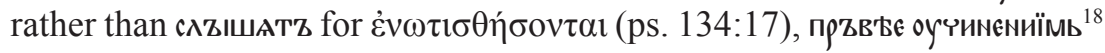

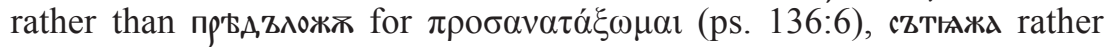

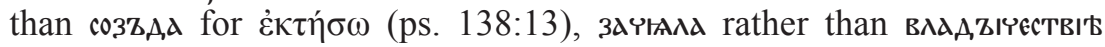

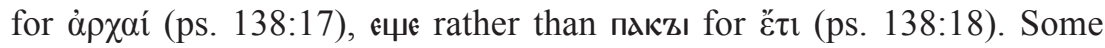
of these reflect not merely different linguistic preferences, but divergent interpretations, and are therefore certainly based on consultation of the Greek text. Other instances are less radically literalistic, but still clear-

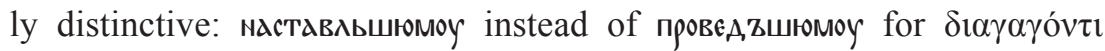

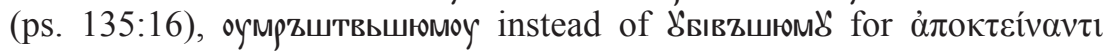

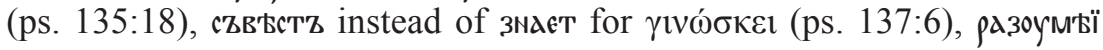

${ }^{18}$ The reading in Ps. Sin seems to be a corruption, perhaps of пръв'ье оучимгт тимz. 


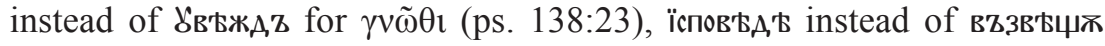
for $\alpha \pi \alpha \gamma \gamma \varepsilon \lambda \tilde{\omega}$ (ps. 141:3). In all the instances just cited, Ps. Dem agrees with the majority reading of the early Church Slavonic psalters against the isolated witness of Ps. Sin; but Ps. Dem has its own translational peculi-

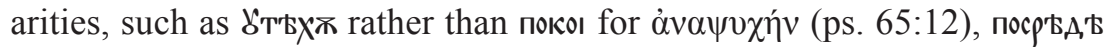

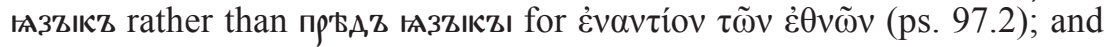
again there is a cluster of them at the end of the psalter text: גютt' rath-

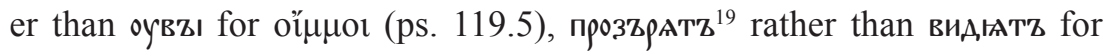

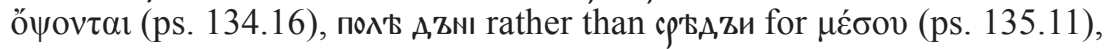

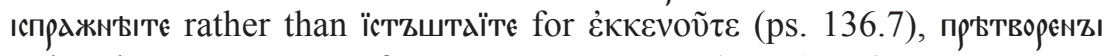

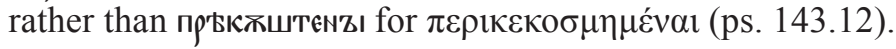

These discrepancies between Ps. Sin and Ps. Dem present an obvious text-critical problem. In each instance, one of the manuscripts goes its own way while the other holds to the majority tradition; but which preserves the reading of the common source? If it is accepted, as argued above, that both the version associated with the pseudo-Athanasian commentary and the Croatian tradition derive, albeit with subsequent revisions, from approximately the same stage in textual development as that source, then by standard text-critical method priority should be accorded to the majority readings which they support. In that case, the isolated readings of Ps. Sin and Ps. Dem may be regarded as innovations. It seems unlikely that they were introduced as part of deliberate revisions undertaken when the two manuscripts were written: both seem to have been copied in haste, and though some attempts at checking and correction were made, they were far from comprehensive. It is more plausible to attribute these textual peculiarities to an earlier process of checking against Greek, either during the production of the common source manuscript, when some glossing was undoubtedly carried out, or possibly at intervening stages of copying; the similarity in their distribution speaks for the former hypothesis.

${ }^{19}$ A similar variant, оузрать, occurs in the Church Slavonic translation of Theodoret (Pogorelov, 1910, 129), but this may be an independent effort to convey the future tense of the Greek. 


\section{B3. Verse division and headings}

The circumstances in which Ps. Sin and Ps. Dem were copied may be relevant to their best preserved and most distinctive shared characteristic, the Constantinopolitan division of the text into verses as well as versicles (Koceva, Karačorova, Atanasova 1985, 39; MacRobert, 1993, 79). This manner of presentation, which is without parallel in the early tradition of the Church Slavonic Psalter, must go back to the common source, and it would have been difficult to change during hurried copying, especially for the scribes of Ps. Sin who, as Lunt and Ilčev observe (Altbauer, 1971, 359; Ilčev, 1980, 95), had to fit their portions of text into the predetermined number of folia in a fascicle. The inclusion of full headings to the psalms and of the diapsalmata also sets Ps. Sin and Ps. Dem apart from other devotional psalter manuscripts which have survived from the period up to the fourteenth century. Like the inherited peculiarities discussed above, these are more fully attested in Ps. Sin than in Ps. Dem, but divergences in their wording and distribution raise in a more acute form the problem outlined under B2: it is not always clear which manuscript contains the older reading (MacRobert, 2014, 176-179). Unfortunately the folia containing the biblical canticles which normally accompany the psalms in Eastern Orthodox practice are lost from Ps. Dem, and so there is no way of telling whether it duplicated the conservative repertoire and order of these texts which characterizes Ps. Sin and, in a slightly different way, the Bologna and Cetinje commentated psalters (MacRobert, 1993, 80; Karačorova, $2005,30-31)$. It is clear, though, that the organization of the text in the common source was closely dependent on a Greek model, and this fact may be further evidence of checking against Greek at that stage.

From these comparisons between Ps. Sin and Ps. Dem a picture of that common source begins to emerge which, though not as detailed as von Arnim's reconstruction, is of significance for the early history of Church Slavonic, as well as for the textual tradition of the Psalter. As Kul'bakin remarks $(1933,254)$, it must have been ,vrlo star”, in textual and perhaps in physical terms: it belonged near the end of the first stage, A1, in the transformation of the text from a Western to a Southern variety of Church Slavonic. It reflected processes of checking against Greek, possibly at the time of writing, certainly in secondary glosses. These drew 
on, and therefore were added after, the Church Slavonic translations of the two commentaries on the psalms. The first and second halves of the manuscript may, as in von Arnim's hypothetical $Y+Z$, have been written by different scribes: it is noticeable that there are more vestigial survivals from stages A1-A2 in the first half, and more signs of glosses and revisions from ps. 77 onward, particularly towards the end of the Psalter. This was a manuscript on which much effort was expended, and which was sufficiently authoritative to serve as exemplar more than once; but it was not a clean copy, and perhaps not entirely easy to read. Its ultimate fate was to be taken apart, fascicle by fascicle, for the convenience of a scribal team who needed to produce a psalter as a rushed job. The result of their work, Ps. Sin, was probably written after the copy was made which served as antigraph to Ps. Dem; and if Ps. Sin was used in turn for further copies, they have not survived. Thus while Ps. Sin casts light on the early development of Church Slavonic, its text is not in all respects the translation of Cyril and Methodius - Ps. Dem and other conservative psalter manuscripts may in some particulars be closer to that starting point - nor did it enjoy wide dissemination. In the textual history of the Church Slavonic Psalter, the Psalterium Sinaiticum is a dead end.

\section{References}

Altbauer, M. (1971). Psalterium sinaiticum. An $11^{\text {th }}$ century Glagolitic Manuscript from St. Catherine's Monastery, Mt. Sinai. Skopje: Macedonian Academy of Sciences and Arts.

Arnim, B. von (1930). Studien zum altbulgarischen Psalterium Sinaiticum. Veröffentlichungen des Slavischen Instituts der Friedrich-Wilhelm-Universität Berlin, 3. Leipzig: Boek- en Steendrukkerij Eduard Ydo (also published as Die Schreiber des Psalterium Sinaiticum und ihre Vorlage, Leipzig).

Dostál, A. (1959). Clozianus. Codex palaeoslovenicus glagoliticus. Prague: Nakladatelství Československé Akademie Věd.

Fetková, P. (2000). Die Schreiber des neugefundenen Teils des Psalterium Sinaiticum. In: Glagolitica. Zum Ursprung der slavischen Schriftkultur. Ed. H. Miklas. Vienna: Verlag der Österreichischen Akademie der Wissenschaften, pp. 109-116.

Hamm, J. (1967). Psalterium vindobonense. Der kommentierte glagolitische Psalter der Österreichischen Nationalbibliothek. Österreichische Akademie der Wissenschaften, Phil.-hist. Klasse, Schriften der Balkankommission, Linguistische Abteilung, 19. Vienna: Böhlau. 
Ilčev, P. (1979). Tekstovata struktura na Sinajskija psaltir. In: Izsledvanija vărxu istorijata i dialektite na bălgarskija ezik. Sbornik v pamet na K. Mirčev. Ed. V.I. Georgiev et al. Sofia: Institut za bălgarski ezik, pp. 200-205.

Ilčev, P. (1980). Sinajskijat psaltir i negovite pisači. In: Slavjanska paleografija i diplomatika. Ed. B. Velčeva et al. Sofia: CIBAL, pp. 89-95.

Jagić, I.V. (1883/1960). Quattuor Evangeliorum versionis palaeoslovenicae codex Marianus glagoliticus. Berlin, reprinted in Graz: Akademische Druck- U. Verlagsanstalt.

Jagić, V.(1907). Slovenskaja psaltyr'. Psalterium bononiense. Vienna-Berlin-St. Petersburg: Vindobonae Gerold.

Karačorova, I. (2005). Kăm izučavaneto na biblejskite pesni v slavjanskata răkopisna tradicija. „Palaeobulgarica”, no. 19, part 1, pp. 25-43.

Koceva, E., Karačorova, I., Atanasov, A. (1985). Nekotorye osobennosti slavjanskix psaltyrej na materiale XI-XVI vv. „Polata k"nigopis'naja”, no. 14-15, pp. 26-75.

Kul'bakin, S. (1924). Psalterium Sinaiticum u novom izdanju. „Južnoslovenski filolog”, no. 4, pp. 166-181.

Kul'bakin, S. (1933). Review of Arnim 1930. „Južnoslovenski fillolog”, no. 12, pp. 242-260.

Lencek, R.L. (1993). 'On the Trail of *vy-Compounds in South Slavic'. In: American contributions to the eleventh international congress of slavists. Ed. R.A. Maguire, A. Timberlake, Columbus-Ohio: Slavica, pp. 344-362.

Lunt, H.G. (1957). Ligatures in Old Church Slavonic Glagolitic manuscripts. „Slavistična revija", no. 10, pp. 253-267.

MacRobert, C.M. (1993). A Missing Link in the Early Tradition of the Church Slavonic Psalter (the Tolstoy, Sluck, Eugenius and Vienna Psalters and MS 34 of the Moscow Synodal Typography). „Wiener slavistisches Jahrbuch”, no. 39, pp. 57-81.

MacRobert, C.M. (2010). The impact of interpretation on the evolution of the Church Slavonic psalter text up to the fifteenth century. In: Congress Volume Ljubljana 2007. Ed. A. Lemaire (Supplements to Vetus Testamentum, 133). Leiden-Boston: Brill, pp. 423-440.

MacRobert, C.M. (2014). On the headings and marginal notes in the two Glagolitic psalter manuscripts in S. Catherine's Monastery on Mount Sinai. In: Philology Broad and Deep: In Memoriam Horace Gray Lunt. Eds. M.S. Flier, D.J. Birnbaum, C.M. Vakareliyska. Bloomington: Slavica Publishers-Indiana University Bloomington, pp. 175-85.

MacRobert, C.M. (2016). The place of Dimitri's Psalter (MS Sinai Slav 3N) in the early transmission of the Church Slavonic Psalter. In: The Bible in Slavic Tradition. Ed.

A. Kulik et al. Leiden-Boston: Brill, pp. 89-106.

Mareš, F.V. (ed.) (1997). Psalterii Sinaitici pars nova. Österreichische Akademie der Wissenschaften, phil.-hist. Klasse, Schriften der Balkan-Kommission, Philologische Abteilung, 38, Fontes Nr. 2. Vienna: Verlag der Österreichischen Akademie der Wissenschaften. 
Marti, R. (2004). Die Bezeichnung der Konsonanten in der Glagolica. In: Glagoljica i hrvatski glagoljizam. Eds. M.-A. Dürrigl, M. Mihaljević, F. Velčić. Zagreb-Krk: Staroslovenski institute-Krčka biskupija, pp. 401- 417.

Miklas, H. et al. (2012). Psalterium Demetrii Sinaitici monasterii sanctae Catharinae codex slav. 3/N adiectis foliis medicinalibus. Vienna: Holzhausen Verlag.

Miklas, H., Gau, M., Hürner, D. (2016). Preliminary Remarks on the Old Church Slavonic Psalterium Demetrii Sinaitici. In: The Bible in Slavic Tradition. Ed. A. Kulik et al. Leiden-Boston: Brill, pp. 21-88.

Mitrevski, Lj. (2000). Dečanski psalter. Prilep: Institut za staroslovenska kultura.

Penkova, P., Karačorova, I. (2003). Sinajski psaltir. In: Kirilo-Metodievska enciklopedija, t. 3. Ed. L. Graševa et al. Sofia: Izdatelstvo na Bălgarskata Akademia na Naukite, pp. 616-622.

Pogorelov, V.A. (1910). Tolkovanija Feodorita Kirrskogo na Psaltyr'v drevne-bolgarskom perevode. Rassmotrenie spiskov i issledovanie osobennostej Psaltyrnogo teksta. Warsaw: Varšavskij učebnyj okrug.

Ribarova, Z. (2005). Jazikot na makedonskite crkvenoslovenski tekstovi. Skopje: MANU.

Sever'janov, S. (1922). Sinajskaja psaltyr'. Glagoličeskij pamjatnik XI veka. Petrograd: Otdelenie russkogo jazyka i slovesnosti Rossijskoj Akademii Nauk.

Šimić, M., Makarijoska, L. (2013). Leksički paraleli vo hrvatskoglagolskite psaltiri i psaltirite od makedonska redakcija. „Kirilometodievistika”, no. 7, pp. 23-42.

Šimić, M., Makarijoska, L. (2015). Leksik hrvatskoglagoljskoga psaltira u usporedbi s psaltirima makedonske redakcije. In: Hrvatsko glagoljaštvo u europskom okružju. Eds. V. Badurina Stipčević, S. Požar, F. Velčić, Zagreb: Staroslavenski institut, pp. $631-646$.

Tarnanides, I.C. (1988). The Slavonic Manuscripts Discovered in 1975 at St. Catherine's Monastery on Mount Sinai. Thessaloniki: Hellēnikē Hetaireia Slabikōn Meletōn.

Temčin, S.Ju. (1998). Piscy Sinajskoj psaltiri po dannym orfografii: digrafnoe i ligaturnoe napisanie št'. In: Meždunarodnyj filologičeskij sbornik v oznamenovanie 150-letija so dnja roždenija F.F. Fortunatova. Ed. V.P. Gudkov. Moscow: Dialog МГУ, pp. 104-115.

Temčin, S.Ju. (2004). Piscy Sinajskoj psaltiri po dannym orfografii: Napisanie bukvy otŭ (omegi). In: Glagoljica i hrvatski glagolizam. Eds. M.-A. Dürrigl, M. Mihaljević, F. Velčić. Zagreb-Krk: Saroslovenski institute-Krčka biskupija, pp. 499-513.

Thomson, F.J. (1998). The Slavonic Translation of the Old Testament. In: Interpretation of the Bible. Ed. J. Krašovec. Ljubljana-Sheffield: Slovenska akademia znanosti in umetnosti, pp. 605-920, especially pp. 797-825.

Vaillant, A. (1932). Review of Arnim 1930. „Revue critique d'histoire et de littérature”, no. 99, pp. 69-73.

Vajs, J. (1916). Psalterium palaeoslovenicum croatico-glagoliticum. Krk-Prague: Sumptibus Academiae Palaeoslavicae Veglensis.

Valjavec, M. (1889-1890). O prevodu psalama u nekijem rukopisima hrvatsko-srpsko 
i bugarsko-slovenskijem. „Rad Jugoslovenske akademije”, no. 98, pp. 1-84; no. 99, pp. 1-53.

Večerka, R. (2012). Anmerkungen zu so genannten Moravismen im Altkirchenslavischen. In: Schnittpunkt Slavistik. Ost und West im wissenschaftichen Dialog. Festgabe für Helmut Keipert zum 70. Geburtstag. Teil 2: Einflussforschung. Ed. I. Podtergera. Bonn: Universitätsverlag "Bonn University Press", pp. 405-414.

Velčeva, B. (1999). Kăsnata bălgarska glagolica. „Kirilo-Metodievski studii”, no. 12, pp. $87-152$.

Velčeva, B. (2000). Bernd von Arnim und die Glagolica. In: Glagolitica. Zum Ursprung der slavischen Schriftkultur. Ed. H. Miklas. Vienna: Verlag der Österreichischen Akademie der Wissenschaften, pp. 43-46. 